\title{
Bio Efficacy of Azoxystrobin in Combination with Pseudomonas fluorescence in Managing Leaf Blight Diseases of Maize
}

\author{
Radhajeyalakshmi Raju*, Sethuraman Kandhasamy, \\ Thukkaiyannan Palaniappan and Arivudainambi Marichamy
}

Maize Research Station, Vagarai-624613, Palani, Tamil Nadu Agricultural University, Tamil Nadu, India

*Corresponding author

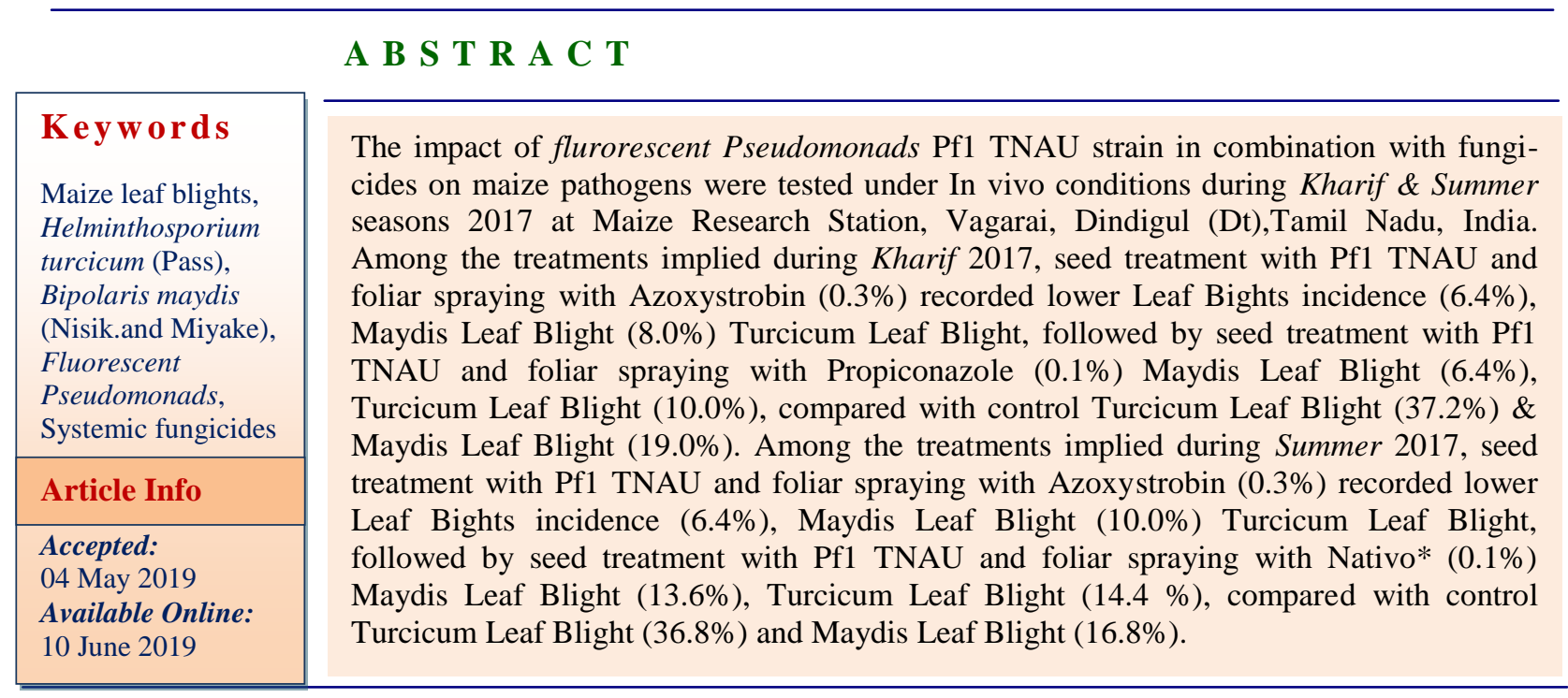

\section{Introduction}

As per the report of CIMMYT and IITA, 2011, rice, wheat and maize are the most important food crops in developing countries. Currently maize production estimated nearly 100 million hectares in 125 developing countries and is among the third most widely grown crops in 75 of those countries (FAOSTAT, 2010). The demand for maize in the developing world will double between now and 2050 and, by 2025, it will become the crop with the greatest production globally as well as in the developing world (Rosegrant et al., 2008). In India, maize is $3^{\text {rd }}$ major crop in India after rice and wheat. The area cultivated with maize in India is 7.27 million ha with an annual production of 15.86 million tones and average yield of $2181 \mathrm{~kg} / \mathrm{ha}$ in 2011-12 (Anon., 2012). Maize can be raised during kharif and rabi in South India (Anand et al., 2013). Among the devastating diseases damaging the maize crop, the turcicum leaf blight Helminthosporium turcicum (Pass) and 
maydis leaf blight Bipolaris maydis (Nisik. and Miyake) are the most important diseases in maize growing areas. Turcicum leaf blight also called as Northern leaf blight of maize caused by Exserohilum turcicum (Pass.) Leonard and Suggs. (Syn. Heliminthosporium turcicum Pass.) is of global importance (Carlos, 1997). In India, the disease is prevalent in almost all the maize growing areas. Severe losses in grain yield due to epiphytotics have been noticed in various parts of India and these losses vary from 25 to 90 per cent depending upon the severity of the disease (Chenulu and Hora, 1962; Jha, 1993, Pant et al., 2000).

Southern Corn Leaf Blight is another most important maize disease and caused by the fungus Bipolaris maydis. Maydis Leaf Blight is reported from most maize growing regions in the world including India. Under severe epiphytotic conditions depending upon the susceptibility of the variety, Maydis Leaf Blight may cause significant grain yield losses (Thompson and Bergquest, 1984), up to $70 \%$ (Kumar et al., 2009).

To minimize the yield losses due to these diseases in maize, effective management practices must be evolved. During the past five years, use of fungicides increased in corn and now a day's corn crop is typically produced with higher fungicide inputs (Wise and Mueller, 2011). Drastic increase in the usage of foliar fungicides over the past 10 years compared to other pesticides in corn (Gianessi and Reigner, 2006). A total of six trials were published that examined the efficacy of fungicides on corn prior to 2008. In between 2008 and 2010, a total of 33 trials were published, which showed the increased interest for research data on corn fungicides (Wise and Mueller, 2011).

Apart from fungicides, usage of growth promoting rhizobacteria in controlling foliar diseases is also widely acceptable practice. Among them, certain fluorescent pseudomonads have received particular attention as potent biofertilizing and bio control agents. Since because, the plantgrowth promotion is related to the biological control of detrimental microorganisms and plant pathogens through the aggressive colonization of root environment, the production of a broad spectrum of extracellular lytic enzymes, siderophores, diverse antibiotics, hydrogen cyanide, or by activation of plant defense-responses (Djuric et al., 2011).

In recent years, the need for integrated approach in managing the diseases of corn is augmented and crucial. Therefore, there is a great demand for new methods to supplement the existing disease management strategies to achieve better blight control. By keeping these views in mind, the present investigation is to find efficient management with the combination of fungicides and growth promoting rhizobacteria for the control of leaf blights Turcicum Leaf Blight \& Maydis Leaf Blight. Experiments were conducted to evaluate the azoxystrobin against leaf blights of maize for two seasons.

\section{Materials and Methods}

\section{Source of fungicides, bio control agents and maize varieties}

In the present investigation, two contact and two systemic fungicides were used to assess their efficacy against leaf blights in combination with Pseudomonas fluorescence Pf1 (TNAU) in CoHM6 maize hybrid.

Trade name, active ingredient and formulation details of fungicides

1. Amistar - Azoxystrobin $25 \mathrm{SC}$

2. Nativo*- Tebuconazole $50 \%+$ 
Trifloxystrobin 25\% w/w WG (75 WG)

3. Indofil M-45 - Mancozeb $75 \%$ WP

4. Tilt -Propiconazole 25\% EC

5. Pseudomonas fluorescence PfI (TNAU)

Testing the efficacy of Pf1 TNAU strain and fungicides under field conditions

The CoHM6 hybrid maize crop was raised with all standard and recommended packages of agronomic practices at the Maize Research Station, Vagarai during Kharif \& Summer seasons of 2017. The test $P f 1$ TNAU strain was applied as seed treatment $(10 \mathrm{~g} / \mathrm{kg})$ and fungicides were applied as foliar spray (0.1 $0.3 \%$ ) with knap sack sprayer fitted with hollow cone nozzle along with test fungicides. About1.25 liters of water was mixed with each test fungicides and sprayed over the crop in each plot measuring $12 \mathrm{~m}^{2}$; first spraying was done at the appearance of visible symptom (45 days after sowing) and second spray was given at 20 leaf stage (Taselling \& Silking). Untreated check (Positive control) was recommended with no $P f 1$ TNAU/fungicide application. Ten plants were marked in each plot for recording percent disease severity following $0-5$ rating scale. At the time of flowering, the length and width of each lesion, and its corresponding position according to the top ear were recorded with regard to no-lesion represents resistance of $\mathrm{Ht} / \mathrm{Hm}$.

\section{Disease score}

The scale consists of five broad categories designated by numerals from 1 to 5 . Intermediate ratings between two numerals $(1.5,2.5,3.5$ etc.) have also been given, thereby providing for a total of nine classes or categories. Wherever possible, observations on lesion types were also made, such as large sporulating wilt type or small chlorotic, non- sporulating type (Data not shown). Data was recorded 30-35 days after sowing, then on flowering and finally just before dough stage. The disease scoring (Payak and Sharma, 1985) was done as per symptoms mentioned below:

Very slight to slight infection, one or two to few scattered lesions on lower leaves. Light infection, moderate number of lesions on lower leaves only. Moderate infection, abundant lesions are on lower leaves, few on middle leaves. Heavy infection, lesions are abundant on lower and middle leaves, extending to upper leaves. Very heavy infection, lesions abundant on almost all leaves plants prematurely dry or killed by the disease.

The plants were kept under close vigil to protect them from the ravages pests' attack. The intensity of the disease was recorded just before each spraying. Disease intensity on leaves was graded in 0-5 rating scale (Payak and Sharma, 1983). The per cent disease intensity (PDI) was calculated by the following formula.

$\mathrm{PDI}=$ Sum of all numerical ratin $\times 100$

Total plants (leaves) observed $\times$ Maximum rating scale used

The details of materials used and method employed in the two experiments were as follows.

Assessment of percentage yield enhancement over to control and Data analysis

The weight and number of the harvested ears were determined and grain yields were computed on a per hectare basis. The disease severity was recorded on an individual plant basis at dough stages. The data thus obtained 
was subjected to statistical analysis following Random Block Design Analysis of Variance (RBD ANOVA) technique.

\section{Results and Discussion}

During Kharif 2017, Seed treatment with Pseudomonas fluorescence Pf1 TNAU and foliar spraying with Azoxystrobin (0.3\%) recorded lower Leaf Bights incidence $(6.4 \%)$, Maydis Leaf Blight (8.0\%) Turcicum Leaf Blight, followed by seed treatment with $P f 1$ and Foliar Spraying with Propiconazole
(0.1\%) Maydis Leaf Blight (6.4\%), Turcicum Leaf Blight (10.0\%), compared with control Turcicum Leaf Blight (37.2\%) and Maydis Leaf Blight (19.0\%).

Seed treatment with Pseudomonas fluorescence Pf1 TNAU and foliar spraying with Azoxystrobin (0.3\%) recorded reduced lesion length of Maydis Leaf Blight $(1.18 \mathrm{~cm})$ \& lesion width (0.32), lesion length of Turcicum Leaf Blight $(2.45 \mathrm{~cm})$, lesion width $(0.32 \mathrm{~cm})$ with increased yield of $8850 \mathrm{~kg} / \mathrm{ha}$ (Table 1-4).

Table.1 In vivo evaluation of bio control agents and fungicides for Southern Maize blight Bipolaris maydis incidence during Kharif 2017

\begin{tabular}{|l|l|l|l|l|l|l|}
\hline S.No & Treatment & $\begin{array}{l}\text { Grade } \\
(\mathbf{0 - 5})\end{array}$ & PDI $(\mathbf{\%})$ & $\begin{array}{l}\text { Leison } \\
\text { Length } \\
(\mathbf{c m})\end{array}$ & $\begin{array}{l}\text { Leison } \\
\text { width } \\
(\mathbf{c m})\end{array}$ & $\begin{array}{l}\text { Yield } \\
\mathbf{( k g / h a )}\end{array}$ \\
\hline T1 & ST-Pf1 + FS -Mancozeb (0.2\%) & 2.46 & 14.8 & 2.25 & 0.37 & 8263 \\
\hline T2 & ST Pf1 + FS-Azoxystrobin (0.3\%) & 1.06 & 6.4 & 1.18 & 0.32 & 8850 \\
\hline T3 & ST -Pf1 + FS-Propiconazole (0.1\%) & 1.46 & 6.4 & 1.33 & 0.40 & 8605 \\
\hline T4 & ST-Pf1+ stripping of lower leaves & 1.93 & 11.6 & 2.16 & 0.46 & 7515 \\
\hline T5 & ST with Pf1 alone & 2.06 & 14.8 & 2.87 & 0.57 & 7025 \\
\hline T6 & FS-Mancozeb (0.2\%) & 2.26 & 13.6 & 2.03 & 0.76 & 7205 \\
\hline T7 & Untreated control & 3.16 & 19.0 & 3.56 & 1.15 & 5030 \\
\hline & & & 0.18 & 0.01 & 0.02 & 1978 \\
\hline
\end{tabular}

ST: Seed Treatment FS: Foliar Spraying

Table.2 In vivo evaluation of bio control agents and fungicides for Northern Maize blight Helminthosporium turcicum incidence during Kharif 2017

\begin{tabular}{|l|l|l|l|l|l|l|}
\hline S.No & Treatment & $\begin{array}{l}\text { Grade } \\
\mathbf{( 0 - 5 )}\end{array}$ & $\begin{array}{l}\text { PDI } \\
\mathbf{( \% )}\end{array}$ & $\begin{array}{l}\text { Leison } \\
\text { Length } \\
\mathbf{( c m )}\end{array}$ & $\begin{array}{l}\text { Leison } \\
\text { width } \\
(\mathbf{c m})\end{array}$ & $\begin{array}{l}\text { Yield } \\
(\mathbf{k g} / \mathbf{h a})\end{array}$ \\
\hline T1 & ST-Pf1+FS-Mancozeb $(0.2 \%)$ & 2.86 & 14.2 & 5.40 & 0.35 & 8263 \\
\hline T2 & ST-Pf1+FS-Azoxystrobin $(0.3 \%)$ & 1.33 & 8.0 & 2.45 & 0.25 & 8850 \\
\hline T3 & ST-Pf1+FS-Propiconazole $(0.1 \%)$ & 2.36 & 10.0 & 2.73 & 0.30 & 8605 \\
\hline T4 & ST-Pf1 + stripping of lower leaves & 2.23 & 14.4 & 3.68 & 0.40 & 7515 \\
\hline T5 & ST with Pf1 alone & 2.56 & 14.8 & 3.50 & 0.45 & 7025 \\
\hline T6 & FS with Mancozeb $(0.2 \%)$ & 2.43 & 17.2 & 4.32 & 0.35 & 7205 \\
\hline T7 & Untreated control & 4.23 & 37.2 & 8.0 & 0.47 & 5030 \\
\hline & CD(0.05) & & 0.133 & 0.033 & 0.017 & 1978 \\
\hline
\end{tabular}

ST: Seed Treatment FS: Foliar Spraying 
Table.3 In vivo evaluation of bio control agents and fungicides for Southern Maize blight Bipolaris maydis during Summer 2017

\begin{tabular}{|l|l|l|l|l|l|l|}
\hline S.No & Treatment & $\begin{array}{l}\text { Grade } \\
\mathbf{( 0 - 5 )}\end{array}$ & $\begin{array}{l}\text { PDI } \\
(\boldsymbol{\%})\end{array}$ & $\begin{array}{l}\text { Leison } \\
\text { Length } \\
\mathbf{( c m )}\end{array}$ & $\begin{array}{l}\text { Leison } \\
\text { width } \\
(\mathbf{c m})\end{array}$ & $\begin{array}{l}\text { Yield } \\
(\mathbf{k g} / \mathbf{h a})\end{array}$ \\
\hline T1 & ST-Pf1 + FS -Mancozeb $(0.2 \%)$ & 2.26 & 11.6 & 1.03 & 0.76 & 7852 \\
\hline T2 & ST Pf1 + FS -Azoxystrobin $(0.3 \%)$ & 1.06 & 6.4 & 0.87 & 0.17 & 8095 \\
\hline T3 & ST -Pf1 + FS - Nativo* (0.1\%) & 1.93 & 13.6 & 1.16 & 0.36 & 7713 \\
\hline T4 & ST-Pf1+ stripping of lower leaves & 2.46 & 14.8 & 2.33 & 0.40 & 7615 \\
\hline T5 & ST with Tv + FS with Pf1 broth & 2.46 & 14.8 & 2.25 & 0.37 & 7305 \\
\hline T6 & FS-Mancozeb (0.2\%) & 2.16 & 13.6 & 2.03 & 0.76 & 7205 \\
\hline T7 & Untreated control & 3.00 & 16.8 & 3.56 & 1.15 & 5030 \\
\hline & CD(0.05) & & 0.148 & 0.014 & 0.010 & 1942 \\
\hline
\end{tabular}

ST: Seed Treatment FS: Foliar Spraying, ${ }^{*}$ Nativo: Trifloxystrobin + Tebuconazole

Table.4 In vivo evaluation of bio control agents and fungicides for Northern Maize blight Helminthosporium turcicum during Summer 2017

\begin{tabular}{|l|l|l|l|l|l|l|}
\hline S.No & Treatment & $\begin{array}{l}\text { Grade } \\
\mathbf{( 0 - 5 )}\end{array}$ & $\begin{array}{l}\text { PDI } \\
\mathbf{( \% )}\end{array}$ & $\begin{array}{l}\text { Leison } \\
\text { Length } \\
\mathbf{( c m )}\end{array}$ & $\begin{array}{l}\text { Leison } \\
\text { width } \\
(\mathbf{c m})\end{array}$ & $\begin{array}{l}\text { Yield } \\
(\mathbf{k g} / \mathbf{h a})\end{array}$ \\
\hline T1 & ST-Pf1 + FS -Mancozeb $(0.2 \%)$ & 2.43 & 14.0 & 3.32 & 0.35 & 7852 \\
\hline T2 & ST Pf1 + FS -Azoxystrobin $(0.3 \%)$ & 1.66 & 10.0 & 2.50 & 0.25 & 8095 \\
\hline T3 & ST -Pf1 + FS - Nativo* (0.1\%) & 2.33 & 14.4 & 3.68 & 0.30 & 7713 \\
\hline T4 & ST-Pf1+ stripping of lower leaves & 2.63 & 17.6 & 4.50 & 0.32 & 7615 \\
\hline T5 & ST with Tv + FS with Pf1 broth & 2.86 & 17.2 & 5.40 & 0.35 & 7305 \\
\hline T6 & FS-Mancozeb (0.2\%) & 2.26 & 17.6 & 2.03 & 0.76 & 7205 \\
\hline T7 & Untreated control & 4.00 & 36.8 & 4.56 & 1.15 & 5030 \\
\hline & CD(0.05) & & 0.115 & 0.017 & 0.019 & 1942 \\
\hline
\end{tabular}

ST: Seed Treatment FS: Foliar Spraying, *Nativo: Trifloxystrobin + Tebuconazole

Among the treatments implied during summer 2017, Seed treatment with Pseudomonas fluorescence Pf1 TNAU and foliar spraying with Azoxystrobin (0.3\%) recorded lower Leaf Bights incidence (6.4\%), Maydis Leaf Blight (10.0\%) Turcicum Leaf Blight, followed by seed treatment with Pseudomonas fluorescence Pfl TNAU and Foliar Spraying with Nativo* $(0.1 \%)$ Maydis Leaf Blight (13.6\%), Turcicum Leaf Blight (14.4\%), compared with control Turcicum Leaf Blight $(36.8 \%)$ \& Maydis Leaf Blight (16.8\%).

Seed treatment with Pseudomonas fluorescence Pf1 TNAU and foliar spraying with Azoxystrobin $(0.3 \%)$ recorded reduced lesion length of Maydis Leaf Blight $(0.87 \mathrm{~cm})$ and lesion width $(0.17 \mathrm{~cm})$, lesion length of Turcicum Leaf Blight $(2.50 \mathrm{~cm})$, lesion width $(0.25 \mathrm{~cm})$ with increased yield of $8095 \mathrm{~kg} / \mathrm{ha}$.

In order to minimize the disease severity which has a profound effect on grain yield loss by using growth promoting rhizobacteria and fungicides at the appropriate dosage and time, farmers can get a higher grain yield and high earnings. By keeping these facts in mind, we have formulated a combination of growth promoting rhizobacteria with fungicide applied as seed treatment and foliar spraying for controlling Turcicum and Maydis blight 
incidence under natural disease incidence. Several studies indicated by investigators (Singh and Gupta, 2000; Patil, 2000; Praveen et al., 2010) that Azoxystrobin (0.3\%) reduced more than $50 \%$ disease over control compared to mancozeb and propiconazole against $E$. turcicum and B.maydis. The present study indicated that the foliar spraying of Azoxystrobin $(0.3 \%)$ reduced the percent disease incidence of the blight incidences in kharif and summer seasons, when the seeds were treated with $P f 1$ with reduced lesion length and lesion diameter.

Propiconazole, demethylation inhibitor (DMI) fungicides has shown the highest efficacy in controlling TLB both in vitro and in field conditions. Quinine oxidation inhibitor (Qol) fungicides, commonly referred as strobilurin has the ability to induce physiological benefits for plants, includes stalk strength, longer preserved green leaf tissue and delayed plant senescence. Delayed senescence either through a reduction in ethylene or in oxidative stress, an increase in photosynthetic capacity and translocation and regulation of the stomatal aperture and improved water-use efficiency (Hooda et al., 2012).

Azoxystrobin appeared to delay the senescence of ginseng plants and increase the ginsenoside with decreased A.panax whetz, disease incidence reported by Liang et al., 2018. Disease protection by way of enhancing the production of CHL content, SP content, and antioxidant enzyme activity protecting the plants from harmful AOS is the additional physiological effect of azoxystrobin that contributes to the enhancement of ginsenoside contents of ginseng leaves (Liang et al., 2018). This study suggests that azoxystrobin plays a vital role in delaying senescence by changing physiological and biochemical indices of ginseng plants. Azoxystrobin treatments to ginseng plants at all growth stages suggested that the delay of senescence will be induced by azoxystrobin due to an enhanced antioxidant enzyme activity protecting the plants from harmful active oxygen species. The oxidative damage induced by ROS was an important signal pathway for the inhibition of fungi by azoxystrobin. The smaller azoxystrobin microsphere exhibited stronger antagonistic activity with a faster dissolution rate of active ingredient and a superior transmembrane permeability (Junwei Yao et al., 2018). With the advent of this strobilurin group of fungicide, we have implied seed treatment with PfI $(10 \mathrm{~g} / \mathrm{kg})$ followed by two sprays of Azoxystrobin $(0.3 \%)$ at 45 days after sowing and 20 leaf stage (taselling \& silking) as blight

\section{Acknowledgements}

This research was financially supported by Non-Plan scheme of Tamil Nadu Agricultural University, Coimbatore-641003, Tamil Nadu, India. The author is thankful to Department of Plant Pathology, Tamil Nadu Agricultural University, Coimbatore-641003 for providing Pseudomonas fluorescence Pf1 culture.

\section{References}

Carlos, D.L. (1997). Diseases of maize in Southeast Asia relevance and management Abstract of the Symposium 'Indian Phytopath. Soc. Golden Jubilee. International Conference on Integrated Plant Disease Management for Sustainable Agriculture, New Delhi, 22.

Chenulu, V.V., Hora, T.S (1962). Studies on losses due to Helminthosporium blight of maize. Indian Phytopathology 15: 235237.

CIMMYT, IITA (2011). Maize - Global Alliance for Improving Food Security and the Livelihoods of the Resource-poor in the Developing World. The proposal submitted by CIMMYT and IITA to the CGIAR Consortium Board, pp1-184.

FAOSTAT (2010). Statistical databases and data-sets of the Food and Agriculture Organization of the United Nations. http://faostat.fao.org/default.aspx (accessed April 2010).

http://www.ifpri.org/themes/impact/impactwate 
r.pdf (accessed March 10, 2010).

Hooda, K.S., Sehar, J.C., Chikkappa, G., Kumar, S., Pandurange, K., T., Sreeramsetty, T.A, et al. (2012). Identifying sources of multiple disease resistance in maize. Maize journal,1,8284.

Jha, M.M (1993). Assessment of losses due to maize diseases in widely grown maize cultivars at Dholi. 18 the Annual Progress Report on Rabi Maize, AICMIP, Indian Agricultural Research Institute, New Delhi. pp. 138.

Junwei Yao, Bo Cui, Xiang Zhao, Heng Zhi, Zhanghua Zeng, Yan Wang, Changjiao Sun, Guoqiang Liu, Jinming Gao and Haixin Cui (2018). Antagonistic Effect of Azoxystrobin Poly (Lactic Acid) Microspheres with Controllable Particle Size on Colletotrichum higginsianum Sacc. Nanomaterials (2018), 8, 857; DOI: 10.3390/nano8100857.

Kumar S, Rani, A (2009). Cultural and nutritional studies in relation to growth and sporulation of Helminthosporium maydis. Ann of Plant Prot. Sci; 17(1):251-52.

Patil, S.J., Wali, M.C., Harlapur, S.I and Prashanth, M (2000). Maize Research in North Karnataka. Bulletin, University of Agricultural Sciences, Dharwad. pp. 54.

Pant, S. K., Kumar, P. and Chauhan, V. S.(2000). Effect of turcicum leaf blight on photosynthesis in maize. Indian Phytopathol, 54: 251-252

Payak, M.M \& Sharma, R. C. (1985). Maize diseases and their approach to their management. Tropical Pest Management. 31: 302-310.

Praveen Kumar M., Narayan Reddy P., Ranga Reddy R and Siva Sankar A. (2010).
Management of Turcicum Leaf Blight Caused by Exserohilum turcicum in Maize. Indian J. Pl. Prot., 38: 63-66.

Djuric, S.A., Pavic, M., Jarak, S., Pavlovic, M., Starovic, R., Pivic, D and Josic (2011). Selection of indigenous fluorescent pseudomonad isolates from maize rhizospheric soil in Vojvodina as possible PGPR .Romanian Biotechnological Letters, Vol. 16, No. 5.

Rosegrant MW, Msangi S, Ringler C, Sulser TB, Zhu T, Cline SA. (2008). International Model for Policy Analysis of Agricultural Commodities and Trade (IMPACT): Model Description. International Food Policy Research Institute: Washington, D.C.

Singh, S. N., A. K. Gupta, Bioassay of fungicides against Dreschlera sativum causing foliar blight of wheat. 52nd Annual Meeting and National Symposium on Role of Resistance on Intensive Agriculture, Directorate of Wheat Research, Karnal (2000), pp. 25.

Shuang Liang, Xuanwei Xu, Zhongbin Lu 1.(2018). Effect of azoxystrobin fungicide on the physiological and biochemical indices and ginsenoside contents of ginseng leaves. J. Ginseng. Res. 42 (2018), 175-182.

Thompson DL, Bergquest RR (1984). Inheritance of mature plant resistance to Helmintosporium maydis race $\mathrm{O}$ in maize. Crop Sci. 24:807 -811.

Wise K, Muelle D. (2011). Are Fungicides No Longer Just for Fungi? An Analysis of Foliar Fungicide Use in Corn.APS net Features. http:www.apsnet.org/publications/apsnet features/pages/fungicide.aspx. Extracted on 10-01-2013.

\section{How to cite this article:}

Radhajeyalakshmi Raju, Sethuraman Kandhasamy, Thukkaiyannan Palaniappan and Arivudainambi Marichamy. 2019. Bio Efficacy of Azoxystrobin in Combination with Pseudomonas fluorescence in Managing Leaf Blight Diseases of Maize. Int.J.Curr.Microbiol.App.Sci. 8(06): 174-180. doi: https://doi.org/10.20546/ijcmas.2019.806.021 